Bidang ilmu : Keperawatan

\title{
HUBUNGAN TINGKAT PENGETAHUAN, SIKAP DAN MOTIVASI IBU DALAM PEMBERIAN STIMULASI DENGAN PERKEMBANGAN ANAK USIA 3-5 TAHUN DI WILAYAH RW 04 KELURAHAN KEDUNG JAYA
}

\author{
Windu Syawalina Wahyuningsih11 \\ Fakultas Ilmu Kesehatan \\ Universitas Pembangunan Nasional Veteran Jakarta \\ windusyawalina@upnvj.ac.id
}

\begin{abstract}
ABSTRAK
Anak adalah individu yang berada pada rentang transisi perkembangan dan rentan mengalami masalah perkembangan. Keterlambatan perkembangan anak dipengaruhi oleh faktor pemberian stimulasi orang tua, khususnya seorang ibu. Penelitian ini bertujuan untuk mengetahui hubungan tingkat pengetahuan, sikap dan motivasi ibu dalam pemberian stimulasi dengan perkembangan anak usia 3-5 tahun di wilayah RW 04 Kelurahan Kedung Jaya. Metode yang digunakan adalah deskriptif analitik dengan teknik proportional random sampling sebanyak 83 ibu dengan anak usia 3-5 tahun. Analisa univariat menggunakan uji proporsi dan analisa bivariat menggunakan uji Chi-Square. Hasil penelitian ini menunjukkan ada hubungan signifikan antara tingkat pengetahuan ibu dalam pemberian stimulasi dengan perkembangan anak yaitu dengan nilai $p$-value $=0,000$, ada hubungan signifikan antara sikap ibu dalam pemberian stimulasi dengan perkembangan anak yaitu dengan nilai $\mathrm{p}$-value $=0,000$, serta ada hubungan signifikan antara motivasi ibu dalam pemberian stimulasi dengan perkembangan anak yaitu dengan nilai $p=$ value 0,000 . Pada penelitian ini, diharapkan ibu mengikuti pelatihan dan sosialisasi tentang stimulasi agar memahami stimulasi yang benar dan tepat. Ibu hendaknya mengikuti pemeriksaan perkembangan anak secara berkala.
\end{abstract}

Kata kunci : Pengetahuan, Sikap, Motivasi, Perkembangan

\section{ABSTRACT}

Children are individuals who in the range of developmental transitions and prone to developmental problems. The delay in child development is influenced by the stimulation of parents, especially a mother. This study aims to determine the relationship between the level of knowledge, attitudes and motivation of mothers in giving stimulation with the development of children aged 3-5 years in the area of RW 04 Kedung Jaya Village. The method used is descriptive analytic with proportional random sampling technique as many as 83 mothers with children aged 3-5 years. Univariate analysis using proportion test and bivariate analysis using Chi-Square test. The results of this study indicate that there is a significant relationship between the mother's level of knowledge in giving stimulation with child development, $\mathrm{p}$-value $=0.000$, there is a significant relationship between mother's attitude in giving stimulation with child development, $\mathrm{p}$-value $=0.000$, and there is a significant relationship between the mother's motivation in giving stimulation with the child's development, $p$ value $=0.000$. In this research, mothers are expected to participate in training and socialization about stimulation in order to understand the correct and appropriate stimulation. Mothers should follow the child's developmental screening on a regular basis.

Keywords : Knowledge, Attitude, Motivation, Development

\footnotetext{
Alamat korespondensi : Cimanggu Gang Mesjid no.37 Bogor

Email

Nomor Hp

: windusyawalina@upnvj.ac.id

: 082141871831
} 


\section{PENDAHULUAN}

Anak adalah individu yang berada pada rentang transisi perkembangan yakni dari masa bayi sampai remaja. Dalam hal ini, anak selaku individu yang unik mempunyai kebutuhan yang beragam dan berbeda berdasarkan tahap perkembangannya. Tahap perkembangan yang akan dilalui anak adalah tahap perkembangan anak prasekolah. Anak prasekolah mengacu pada usia 3-5 tahun. Pada tahap tersebut, anak sangat rentan mengalami masalah perkembangan.

UNICEF (2018) dalam Riyadi \& Sundari (2020) mencatat bahwa urutan ke-4 di dunia dengan jumlah anak terbanyak ialah Indonesia. Jumlah anak pra-sekolah di Indonesia sekitar 21.990 ribu jiwa. Namun, dari jumlah tersebut, Indonesia tidak terlepas dari permasalahan kesehatan yaitu sekitar 56,34\% anak prasekolah mengalami keterlambatan perkembangan. Hasil skrining perkembangan anak di 30 provinsi diperoleh data gangguan perkembangan anak dengan persentase 45,12\% (Devi Firdaus, 2018).

Pernyataan diatas didukung oleh laporan Depkes RI dalam Prastiwi (2019) menunjukkan sebesar 16\% balita di negara Indonesia terjadi gangguan perkembangan motorik kasar dan halus, gangguan pendengaran, penurunan kecerdasan dan keterlambatan bicara. Sekitar 559 juta anak berusia dibawah 5 tahun yang berada di negara berkembang telah mengalami keterlambatan perkembangan, khususnya terjadi pada delapan juta anak di Indonesia (Mulyanti et al., 2017).

Keterlambatan perkembangan pada anak dipengaruhi oleh faktor pemberian stimulasi orang tua. Kurangnya stimulasi mengakibatkan keterlambatan perkembangan pada anak. Disebutkan dalam penelitian Hati, Febrina Suci; Lestari (2017), di usia $<4$ tahun, jaringan otak anak akan berkembang sampai $80 \%$ jika memperoleh banyak stimulasi. Tetapi, pada anak yang tidak diberi stimulasi, jaringan otaknya mengecil yang mengakibatkan menurunnya fungsi otak. Ini menjadi sebab terjadinya keterlambatan perkembangan anak.

Studi literatur dari Salifah (2020) menyatakan terdapat hubungan stimulasi orang tua terhadap kesesuaian tumbuh kembang anak usia prasekolah. Stimulasi menjadi hal yang penting untuk dilakukan. Hal itu dibuktikan dalam penelitian Aboud \& Yousafzai (2019) bahwa stimulasi diperlukan untuk perkembangan kognitif dan bahasa anak-anak dari usia 3 tahun. Sebanyak 43\% anak di bawah 5 tahun tidak mencapai perkembangan mental dan sosialnya sebab kurang diberikan stimulasi.

Anggraeni (2018) menguraikan dalam penelitian bahwa orang tua terkadang memakai metode kekerasan baik fisik atau verbal dalam mendisiplinkan anak sehingga meninggalkan dampak psikologis yang membuat perkembangan anak terganggu. Kejadian tersebut terjadi dikarenakan kekurangtahuan stimulasi dari orang tuanya. Orang tua khususnya ibu perlu memperkaya pengetahuan terkait stimulasi anak. Penelitian Hamidah Hanim \& Issn (2020) mengemukakan bahwa melalui pengetahuan yang baik tentang cara pemberian stimulasi, dapat membantu anak menguasai tugas perkembangan dan mencapai perkembangan yang optimal.

Disisi lain, hal yang mempengaruhi perkembangan anak adalah sikap. Katharina \& Iit (2018) mengungkapkan ibu yang bersikap mendukung akan selalu sadar memantau pertumbuhan dan perkembangan anaknya hingga anak bisa berkembang secara optimal sesuai usianya. Hasil tersebut berbeda dengan kesimpulan penelitian Wijayanti \& Edmiandini (2017) bahwa tidak ada hubungan sikap ibu tentang stimulasi perkembangan dengan tahap perkembangan anak usia 3-4 tahun. Kedua pernyataan diatas saling bertentangan, maka dari itu perlu penelitian lebih lanjut.

Berdasarkan penelitian Zukhra \& Amin (2017), kesadaran dan kemampuan ibu dalam pemberian stimulasi, lingkungan positif, dan motivasi ibu turut berperan dalam proses perkembangan anak. Ibu yang memiliki motivasi dalam pemberian stimulasi kemungkinan besar akan mempunyai banyak alasan untuk lebih tekun dan yakin mengoptimalkan perkembangan anak. Sebaliknya, tidak adanya motivasi ibu dalam pemberian stimulasi akan memicu terjadinya pengabaian aspek perkembangan anak.

Keterlambatan pada aspek tumbuh kembang diantaranya bahasa, motorik halus dan kasar, kemandirian serta personal sosial. Anak yang mengalami keterlambatan bahasa hanya mempunyai jumlah kosakata yang terbatas sehingga menghambat proses sosialisasi, sebab anak tidak/ kurang mampu menyampaikan pendapatnya. Anak dengan keterlambatan motorik akan berjalan, duduk dan merangkak lebih lambat ketimbang anak seusianya (Berlianti, Sundari, \& Mashudi, 2020). 
Yunita, Luthfi, \& Erlinawati (2020) menguraikan bahwa dampak diatas terbawa hingga anak bersekolah, anak mengalami kesulitan membaca, menulis, dan lambat laun terjadi keterbelakangan mental serta gangguan perkembangan syaraf. Kurangnya stimulasi pun berdampak pada kesiapan bersekolah. Anak cenderung mengalami frustasi di sekolah, berperilaku menarik diri, apatis, menampakkan sikap mogok sekolah, sampai mengganggu fungsi kemandirian dan sosial anak. Jika dampak tersebut terus diabaikan, maka akan mengancam kelanjutan perkembangan anak (Asiyah, 2018).

Studi pendahuluan yang dilakukan di Kelurahan Kedung Jaya tepatnya di Wilayah RW 04 dilaksanakan saat masa Pandemi Covid-19, dimana fasilitas kesehatan seperti posyandu dan puskesmas tutup untuk melayani ibu dengan anak. Sebagian besar ibu mengatakan tidak begitu khawatir dengan proses perkembangan anaknya, sebab sejauh ini mereka menganggap bahwa anak mereka sehat dan baik baik saja walaupun tidak dilakukan pemeriksaan tumbuh kembang.

Dari hasil studi pendahuluan dengan 10 ibu dengan anak usia 3-5 tahun diperoleh 6 responden kurang mengetahui stimulasi, memiliki sikap kurang mendukung ke anak, dan tidak termotivasi, 3 orang ibu mengetahui stimulasi, kurang mendukung ke anak dan termotivasi memberikan stimulasi, dan 1 orang ibu mengetahui stimulasi, mendukung anak, serta termotivasi dalam memberikan stimulasi perkembangan agar anak bisa berkembang secara optimal.

Berdasarkan uraian di atas, peneliti tertarik mengambil judul "Hubungan Tingkat Pengetahuan, Sikap dan Motivasi Ibu dalam Pemberian Stimulasi dengan Perkembangan Anak Usia 3-5 Tahun di Wilayah RW 04 Kelurahan Kedung Jaya"

\section{METODE PENELITIAN}

Metode yang digunakan dalam penelitian ini yaitu deskriptif analitik dengan desain crosssectional. Populasi dalam penelitian adalah ibu yang mempunyai anak usia 3-5 tahun di Wilayah RW 04 Kelurahan Kedung Jaya sebanyak 105 ibu dengan anak usia 3-5 tahun.Teknik sampel yang digunakan ialah probability samples dengan teknik proportional random sampling sehingga diperoleh sebanyak 83 ibu dengan anak usia 3-5 tahun. Sampel dari penelitian ini adalah ibu dengan anak usia 3-5 tahun yang mengacu pada kriteria inklusi penelitian diantaranya ibu yang memiliki anak usia 35 tahun di wilayah RW 04 Kelurahan Kedung Jaya, ibu dan anak bersedia menjadi responden, ibu yang mampu membaca dan menulis, ibu yang tinggal bersama anak balitanya. Sedangkan, kriteria eksklusi penelitian ini adalah ibu dengan anak balita yang usianya $<3$ tahun, ibu dengan anak balita yang memiliki kelainan fisik sejak lahir, ibu dengan anak yang sedang sakit atau sedang menjalani pengobatan, ibu dengan anak yang dirawat di Rumah Sakit (RS), serta tidak bersedia mengikuti penelitian.

Penelitian ini menggunakan kuesioner sebagai instrumen penelitian. Kuesioner yang disebar adalah kuesioner yang sudah di uji validitas dan reliabilitas kepada 30 responden. Pernyataan yang dimasukkan dalam kuesioner tingkat pengetahuan sebanyak 15 item, sikap 10 item, dan motivasi 20 item. Validitas kuesioner yang menggunakkan uji korelasi product moment memperoleh $\mathrm{r}$ hitung $\geq \mathrm{r}$ tabel 0,361, artinya pernyataan seluruh kuesioner adalah valid. Adapun hasil uji reliabilitas pada kuesioner tingkat pengetahuan dengan nilai Cronbach's Alpha 0,694 (>0,60-0,80). hasil uji reliabilitas kuesioner sikap ibu dengan nilai Cronbach's Alpha 0,651 ( $>0,60-0,80)$. Selanjutnya, hasil uji reliabilitas kuesioner motivasi ibu yang disusun oleh peneliti diperoleh semua pernyataan reliabel dengan nilai Cronbach's Alpha 0,721 (>0,60-0,80). Untuk penilaian perkembangan anak menggunakkan Kuesioner Pra Skrining Perkembangan (KPSP). Teknik pengolahan data menggunakan Uji Chi Square dengan program SPSS. Penelitian dilakukan setelah mendapatkan izin etik pada institusi Universitas Pembangunan Nasional Veteran Jakarta dengan nomor B/287/VI/2021/KEPK 


\section{HASIL DAN PEMBAHASAN}

\section{a. Analisis Univariat}

Tabel 1 Data responden berdasarkan Usia Anak

\begin{tabular}{ccc}
\hline Usia Anak & Frekuensi & Presentase (\%) \\
\hline 3 tahun ( 36 bulan - 42 bulan) & 31 & 37,3 \\
4 tahun (48 bulan - 54 bulan) & 31 & 37,3 \\
5 tahun (60 bulan - 66 bulan) & 21 & 25,3 \\
\hline Total & 83 & 100 \\
\hline
\end{tabular}

Hasil analisa tabel 1 menunjukkan dari 83 responden, anak usia 3 tahun ( 36 bulan - 42 bulan) sebanyak 31 responden (37,3\%), sama jumlahnya dengan anak usia 4 tahun (48 bulan - 54 bulan) sebanyak 31 responden (37,3\%), dan minoritas berada pada rentang usia 5 tahun ( 60 bulan - 66 bulan) sebanyak 21 responden (27,3\%). Hasil serupa ditunjukkan oleh Meilawati (2017) di Paud Al Falah Desa Bibrik Kecamatan Jiwan Kabupaten Madiun yang mana mayoritas anak memiliki usia 4 tahun sebanyak $25(78,1 \%)$ anak dan anak dengan usia 3 tahun sebanyak $7(21,9 \%)$ anak.

Tabel 2 Data responden berdasarkan Usia Ibu

\begin{tabular}{rcc}
\hline Usia Ibu & Frekuensi & Presentase (\%) \\
\hline 24-33 tahun & 46 & 55,4 \\
34-43 tahun & 26 & 31,3 \\
$44-53$ tahun & 11 & 13,3 \\
\hline Total & 83 & 100 \\
\hline
\end{tabular}

Hasil analisa tabel 2 menunjukkan dari 83 responden mayoritas usia responden berada pada rentang 24-33 tahun sebanyak 46 responden $(55,4 \%), 26$ responden $(31,3 \%)$ berada pada rentang usia 34-43 tahun dan 11 responden (13,3\%) lainnya berada pada rentang 44-53 tahun. Usia tersebut merupakan usia yang matang untuk berkeluarga, baik mengurus dan mendidik anak. Pada usia yang berkisar antara 24-33 tahun, ibu juga masih aktif dalam menemukan informasi dan mudah menerima materi yang diberikan kepadanya. Hasil analisis ini searah dengan teori Notoatmodjo (2010) yang menyebutkan seseorang dengan usia reproduktif lebih mudah menerima pengetahuan dan informasi.

Tabel 3 Data responden berdasarkan Jenis Kelamin

\begin{tabular}{|c|c|c|}
\hline Jenis Kelamin & Frekuensi & Presentase (\%) \\
\hline Laki-laki & 45 & 54,2 \\
\hline Perempuan & 38 & 45,8 \\
\hline Total & 83 & 100 \\
\hline
\end{tabular}

Hasil analisa pada tabel 3 menunjukkan dari 83 responden mayoritas jenis kelamin anak adalah laki-laki sebanyak 45 responden (54,2\%), dan anak dengan jenis kelamin perempuan sebanyak 38 responden $(45,8 \%)$. Penelitian yang searah dari Riyadi \& Sundari (2020) memperoleh hasil bahwa paling banyak anak berjenis kelamin laki-laki sebanyak 22 (67,6\%). Data Kemenkes RI (2016) menyatakan jenis kelamin menjadi faktor pengaruh pertumbuhan dan perkembangan. Pernyataan ini dapat dibuktikan oleh penelitian yang menjelaskan stimulasi sangat berpengaruh pada perkembangan kecerdasan anak, setelah anak diberikan perlakuan berupa stimulasi, nilai full IQ sesuai jenis kelamin diperoleh perbedaan sebesar 5-6,6 unit antara perempuan dan laki laki usia 3-6 tahun (Siswina et al., 2016). 
Hal tersebut terjadi karena perkembangannya anak perempuan lebih cepat dimulai dikenal dengan periode pre-adolescent growth. Namun karena perkembangannya terjadi lebih dulu, menyebabkan lebih cepat berhenti dibanding anak laki-laki, hal ini dialami karena faktor hormonal. Karena itu, perkembangan anak perempuan jauh lebih cepat menurun dibanding anak laki-laki, bila stimulasi yang diberikan tidak berkesimbungan, maka kecerdasan anak perempuan akan hilang, hingga anak laki laki tampak lebih menonjol perekembangannya (Siswina et al., 2016).

Tabel 4 Data responden berdasarkan Tingkat Pendidikan Ibu

\begin{tabular}{|c|c|c|}
\hline Tingkat Pendidikan & Frekuensi & Presentase (\%) \\
\hline Rendah (SD/SMP) & 31 & 37,3 \\
\hline Menengah (SMA/SMK) & 35 & 42,2 \\
\hline Tinggi (Diploma/Sarjana) & 17 & 20,5 \\
\hline Total & 83 & 100 \\
\hline
\end{tabular}

Hasil analisa pada tabel 12 menunjukkan dari 83 responden mayoritas memiliki tingkat pendidikan menengah (SMA/SMK) sebanyak 35 responden $(42,2 \%), 31$ responden $(37,3 \%)$ memiliki tingkat pendidikan rendah (SD/SMP), dan responden dengan tingkat pendidikan tinggi (Diploma/Sarjana) hanya 17 responden $(20,5 \%)$. Hasil diatas sejalan dengan penelitian milik Mulyanti et al (2017) bahwa dari 163 responden, menunjukkan sebanyak 108 ibu (66,3\%) memiliki tingkat pendidikan menengah (SMA/Sederajat). Riyadi \& Sundari (2020) mengungkapkan Ibu yang yang menempuh pendidikan yang tinggi akan mendapatkan pengetahuan lebih banyak dibanding dengan yang berpendidikan rendah. Ibu dengan tingkat pendidikan yang tinggi juga lebih mudah memahami informasi dari berbagai sumber, terutama informasi tentang stimulasi anak. Dengan begitu, akan mendukung peran ibu dalam memberikan stimulasi perkembangan kepada anak.

Tabel 5 Data responden berdasarkan Status Pekerjaan

\begin{tabular}{|c|c|c|}
\hline Status Pekerjaan Ibu & Frekuensi & Presentase (\%) \\
\hline Tidak Bekerja/IRT & 65 & 78,9 \\
\hline Bekerja & 18 & 21,7 \\
\hline Total & 83 & 100 \\
\hline
\end{tabular}

Hasil analisa pada tabel 5 menunjukkan dari 83 responden mayoritas memiliki status tidak bekerja/IRT sebanyak 65 responden $(78,9 \%)$ dan responden yang memiliki status aktif bekerja sebanyak 18 responden (21,7\%). Hasil ini serupa dengan penelitian dari Endarwati \& Haqiqi (2019) terhadap 54 responden, sebagian besar memiliki status tidak bekerja/IRT sebanyak 43 responden $(80 \%)$. Pada penelitian ini, ditemukan beberapa ibu dengan status bekerja tetap bisa memberikan stimulasi kepada anaknya meskipun tidak bisa dilakukan secara rutin, berbeda dengan ibu yang berada dan bersama anak di rumah, mereka memiliki kesempatan bermain dan mampu menstimulasi lebih banyak serta rutin. Selain itu, anak terlihat lebih dekat dan memiliki hubungan emosional yang kuat dengan ibunya. Hal tersebut bisa dibuktikan dengan penelitian Riyadi \& Sundari, (2020) yang mengungkapkan akan kedekatan hubungan antara ibu dan anak lebih tinggi pada orang tua yang tidak bekerja dibandingkan dengan ibu yang bekerja.

Analisis dari hasil penelitian ini memperlihatkan bahwa ibu bekerja memiliki peran ganda yaitu peran sebagai wanita karir dan juga ibu rumah tangga. Salah satu risiko dari ibu yang bekerja ialah tidak bisa memberikan perhatian sepenuhnya pada anak selama anak berada pada tahap perkembangan yang pesat. Padahal sebenernya ibu memegang peran yang penting untuk mengasuh anak. Hasil wawancara dengan ibu dengan status bekerja, kebanyakan memiliki waktu hanya setengah hari bersama anaknya karena ibu bekerja sampingan seperti buruh dan seringkali banyak kehilangan waktu untuk bersama anak. Berdasarkan uraian diatas, dapat disimpulkan mayoritas ibu tidak bekerja/IRT di Wilayah RW 04 Kelurahan Kedung Jaya. 
Tabel 6 Distribusi Responden berdasarkan Tingkat Pengetahuan Ibu dalam Pemberian Stimulasi

\begin{tabular}{|c|c|c|}
\hline Tingkat Pengetahuan Ibu & Frekuensi & Presentase $(\%)$ \\
\hline Baik & 35 & 42,2 \\
\hline Kurang & 48 & 57,8 \\
\hline Total & 83 & 100 \\
\hline
\end{tabular}

Hasil analisa pada tabel 6 menunjukkan dari 83 ibu mayoritas memiliki tingkat pengetahuan kurang dalam memberikan stimulasi kepada anak sebanyak 48 responden (52,7\%) dan ibu yang memiliki tingkat pengetahuan baik dalam memberikan stimulasi kepada anak sebanyak 35 responden (42,2\%). Hasil diatas sejalan dengan penelitian Riyadi \& Sundari (2020) yakni menunjukkan terhadap 34 responden, 19 responden (55,9\%) diantaranya memiliki pengetahuan kurang dan $15(44,1 \%)$ lainnya berpengetahuan baik. Tabel diatas menunjukkan bahwa mayoritas ibu memiliki tingkat pengetahuan kurang. Menurut Wawan \& M (2018), tingkat pengetahuan yang kurang ditandai dengan ketidakmampuan seseorang dalam mengetahui, memahami, mengaplikasi, menganalisis, mensintesis, dan mengevaluasi suatu materi.

Dalam penelitian ini, ditemukan mayoritas ibu berpengetahuan kurang dilihat dari tanggapan responden yakni menjawab salah pada pernyataan terkait stimulasi seperti perkembangan memerlukan rangsangan atau stimulasi dan pernyataan bahwa stimulasi adalah kegiatan merangsang kemampuan dasar anak usia 0-6 tahun. Ibu juga tidak dapat memahami serta menganalisa beberapa bentuk stimulasi sesuai aspek perkembangan anak.Pengetahuan seorang ibu sangatlah berguna untuk keseluruhan proses perkembangan anak, karena dengan dasar pengetahuan yang kuat ibu mampu mengenali proses perkembangan anaknya serta memberikan stimulasi rutin dalam aspek perkembangan meliputi motorik kasar, halus, bicara atau bahasa maupun sosialisasi serta kemandirian. Kemudian ketika ibu memiliki pengetahuan baik maka akan cenderung mempunyai sikap yang positif dimana ibu akan melatih atau melakukan segala sesuatu sesuai dengan yang diketahuinya, seperti pemberian stimulasi anak sesuai usianya. Hasil analisis dalam penelitian tingkat pengetahuan ibu tentang stimulasi dapat berbeda di Wilayah RW 04 Kelurahan Kedung Jaya karena kurangnya sosialisasi pengetahuan tentang stimulasi, langkah stimulasi dan kegunaannya. (Jasmawati \& Ratnawati, 2016).

Tabel 7 Distribusi Responden berdasarkan Sikap Ibu dalam Pemberian Stimulasi

Sikap Ibu Frekuensi $\quad$ Presentase (\%)

\begin{tabular}{|c|c|c|}
\hline Positif & 39 & 47 \\
\hline Negatif & 44 & 53 \\
\hline Total & 83 & 100 \\
\hline
\end{tabular}

Hasil analisa pada tabel 7 menunjukkan dari 83 ibu mayoritas memiliki sikap negatif dalam pemberian stimulasi kepada anak sebanyak 44 responden (53\%) dan ibu yang memiliki sikap positif dalam pemberian stimulasi kepada anak hanya 39 responden (47\%). Tabel diatas menunjukkan bahwa mayoritas ibu memiliki sikap negatif. Wawan \& M, (2018) mengungkapkan sikap ibu dalam memberikan stimulasi perkembangan hendaknya memiliki sikap positif seperti menerima, merespon, menghargai dan bertanggung jawab atas perkembangan anak. Ibu dengan sikap positif cenderung menerima akan pentingnya informasi tentang stimulasi dan perlu melatih kemampuan dasar anak. Selain itu, sikap negatif dinilai saat ibu merasa senang dan mampu menghargai setiap respon dari anak yang diberi stimulasi. Tetapi dalam penelitian ini, didominasi oleh sikap negatif dari ibu, sikap negatif ditunjukkan dengan jawaban terhadap pernyataan dimana mayoritas ibu merasa setuju jika anak akan berkembang dengan sendirinya, maka ibu tidak perlu memberikan stimulasi. Adapun pernyataan responden dimana ibu merasa keberatan memberikan stimulasi pada anak karena tidak punya waktu, hal ini berkaitan dengan ibu yang bekerja. Kedua pernyataan diatas 
menggambarkan bahwa tanggung jawab untuk memberikan stimulasi kepada anak tidak dilakukan oleh ibu serta menjadi wujud dari sikap negatif.

Apabila sikap yang diberikan cenderung negatif saat ibu memberikan stimulasi maka perkembangan anak juga tidak dapat berkembang atau bisa mengalami penyimpangan. Sebaliknya, jika ibu memberikan sikap positif maka perkembangan anak juga dapat berkembang dengan sesuai (Wijayanti \& Edmiandini, 2017). Hasil analisis dari penelitian ini memperlihatkan hal itu terjadi karena sebagian besar ibu masih tidak begitu mengerti tentang stimulasi, sehingga masih banyak hasil sikap negatif. Kondisi ini pun dipengaruhi oleh berbagai faktor. Menurut beberapa teori, faktor eksternal atau internal turut serta mempengaruhi pembentukan sikap. Maka, sangat penting memperoleh pengalaman dan pembelajaran dari tenaga kesehatan atau lainnya, sebab sikap bukanlah bawaan lahir, tetapi bisa dipelajari dan dibentuk berdasarkan pengalaman yang dialami serta latihan yang biasa dilakukan selama periode perkembangan anak (Katharina \& Iit, 2018).

Tabel 8 Distribusi Responden berdasarkan Motivasi Ibu dalam Pemberian Stimulasi

Motivasi Ibu $\quad$ Frekuensi $\quad$ Presentase (\%)

\begin{tabular}{lll}
\hline Termotivasi & 37 & 44,6 \\
Tidak Termotivasi & 46 & 55,4 \\
\hline \multicolumn{1}{c}{ Total } & 83 & 100 \\
\hline
\end{tabular}

Hasil analisa pada tabel 8 menunjukkan dari 83 ibu mayoritas tidak termotivasi memberikan stimulasi kepada anak sebanyak 46 responden $(55,4 \%)$ dan ibu yang termotivasi memberikan stimulasi kepada anak jumlahnya hanya 37 responden $(44,6 \%)$. Tabel diatas menunjukkan bahwa mayoritas ibu tidak termotivasi. Analisis dari penelitian ini, responden yang tidak memiliki motivasi juga cenderung tidak memberikan stimulasi, karena kebanyakan ibu menganggap bahwa anaknya akan berkembang dengan sendirinya. Kemudian, tidak sedikit ibu yang merasa lebih bersemangat untuk memberikan stimulasi hanya ketika mendapatkan bantuan dan dukungan dari orang tua, setelah tidak ada bantuan, maka ibu merasa stimulasi tidak menjadi hal yang diprioritaskan untuk anaknya. Peneliti juga menemukan bahwa beberapa ibu yang memiliki status aktif bekerja bisa kehilangan waktu untuk mendampingi anak sepenuhnya. Setelah ibu pulang bekerja, ibu seringkali terfokus pada pekerjaan rumahnya dan sudah merasa lelah menemani anaknya.

Tabel 9 Distribusi Responden berdasarkan Perkembangan Anak

\begin{tabular}{|c|c|c|}
\hline Perkembangan Anak & Frekuensi & Presentase $(\%)$ \\
\hline Sesuai & 31 & 37,3 \\
\hline Meragukan & 36 & 43,4 \\
\hline Ada Penyimpangan & 16 & 19,3 \\
\hline Total & 83 & 100 \\
\hline
\end{tabular}

Hasil analisa pada tabel 9 menunjukkan dari 83 anak dengan usia 3-5 tahun memiliki perkembangan yang sesuai sebanyak 31 responden $(37,3 \%)$ dan perkembangan yang meragukan 36 responden $(43,4 \%)$ serta lainnya 16 responden $(19,3 \%)$ terjadi penyimpangan pada perkembangannya. Tabel diatas menunjukkan bahwa mayoritas perkembangan anak berada pada perkembangan yang meragukan. Analisis pada penelitian ini menunjukkan bahwa perkembangan anak dinilai meragukan disebabkan oleh situasi pemeriksaan perkembangan di lapangan, ada minoritas anak kurang mengikuti arahan pemeriksa, adapun anak bersikap rewel, malu serta belum terbiasa dengan hadirnya orang yang baru dikenalnya.

Menurut Sugeng, Tarigan, dkk (2019) perkembangan anak disebut meragukan jika pada pemeriksaan KPSP saat penelitian, hanya mendapat jawaban "Ya" sebanyak 7-8 poin. Anak tidak bisa melakukan beberapa kemampuan yang seharusnya dicapai usianya. Melihat hasil tersebut, perlu memberikan petunjuk ke ibu agar melakukan stimulasi pada anak lebih rutin, dan melakukan pemeriksaan kesehatan untuk mencari adanya kemungkinan penyakit yang menyebabkan 
penyimpangan perkembangan. Mulyanti et al., (2017) mengungkapkan dimana perbedaan kategori perkembangan dipengaruhi oleh multifaktor meliputi faktor genetik, gizi, stimulasi psikososial, motivasi belajar, ganjaran atau hukuman yang wajar, kelompok sebaya, tingkat stress, kualitas interaksi orang tua, status ekonomi keluarga, tingkat pendidikan orang tua, jumlah saudara, stabilitas rumah tangga, ajaran agama dan sebagainya. Berdasarkan uraian diatas dapat disimpulkan mayoritas perkembangan anak di Wilayah RW 04 Kelurahan Kedung Jaya berada pada perkembangan yang meragukan.

\section{b. Analisis Bivariat}

Tabel 10 Hubungan Tingkat Pengetahuan Ibu dalam Pemberian Stimulasi dengan Perkembangan Anak Usia 3-5 Tahun

\begin{tabular}{|c|c|c|c|c|c|c|c|c|c|}
\hline \multirow{3}{*}{$\begin{array}{c}\text { Tingkat } \\
\text { Pengetahuan } \\
\text { Ibu }\end{array}$} & \multicolumn{6}{|c|}{ Perkembangan Anak } & \multirow{2}{*}{\multicolumn{2}{|c|}{ Total }} & \multirow[t]{3}{*}{$\begin{array}{c}P- \\
\text { Value }\end{array}$} \\
\hline & \multicolumn{2}{|c|}{ Sesuai } & \multicolumn{2}{|c|}{ Meragukan } & \multicolumn{2}{|c|}{ Ada Penyimpangan } & & & \\
\hline & $\mathbf{n}$ & $\%$ & $\mathbf{n}$ & $\%$ & $\mathbf{n}$ & $\%$ & $\mathbf{n}$ & $\%$ & \\
\hline Baik & 31 & 88,6 & 4 & 11,4 & 0 & 0 & 35 & 100 & 0,000 \\
\hline Kurang & 0 & 0 & 32 & 66,7 & 16 & 33,3 & 48 & 100 & \\
\hline Total & 31 & 37,3 & 36 & 43,4 & 16 & 19,3 & 83 & 100 & \\
\hline
\end{tabular}

Berdasarkan pada tabel 10 terhadap 83 responden menunjukkan bahwa ibu dengan tingkat pengetahuan baik memiliki anak yang perkembangannya sesuai sebanyak 31 anak (88,6\%), ibu yang memiliki tingkat pengetahuan baik memiliki anak dengan perkembangan meragukan sebanyak 4 anak $(11,4 \%)$. Sedangkan, ibu yang memiliki tingkat pengetahuan kurang memiliki anak dengan perkembangan meragukan sebanyak 32 anak $(66,7 \%)$ serta anak yang perkembangannya menyimpang sebanyak 16 anak $(33,3 \%)$.

Berdasarkan hasil uji Chi Square diperoleh hasil nilai p sebesar 0,000 < 0,05. Maka, dapat disimpulkan bahwa $\mathrm{H} 0$ diterima dan $\mathrm{H} 1$ ditolak, berarti terdapat hubungan signifikan antara tingkat pengetahuan ibu dalam pemberian stimulasi dengan perkembangan anak usia 3-5 tahun. Menurut Notoatmodjo (2011), pengetahuan adalah hasil dari 'tahu' yang terjadi setelah individu melakukan pengindraan pada objek tertentu. Domain pengetahuan menjadi domain penting dalam pembentukan perilaku seseorang. Pengetahuan seorang ibu sangatlah berguna untuk keseluruhan proses perkembangan anak, karena dengan dasar pengetahuan yang kuat ibu mampu mengenali proses perkembangan anaknya serta memberikan stimulasi rutin dalam aspek perkembangan meliputi motorik kasar, halus, bicara atau bahasa maupun sosialisasi serta kemandirian. (Jasmawati \& Ratnawati, 2016)

Ibu perlu memahami aspek-aspek perkembangan agar anak bisa berkembang optimal serta sesuai anak seusianya. Upaya utama yang mendukung perkembangan optimal yakni memberikan stimulasi sebagai kebutuhan asah. Stimulasi ialah aktivitas merangsang kemampuan dasar anak yang dilakukan oleh lingkungan terdekat anak untuk mempercepat tumbuh kembang. Terlebih, perkembangan anak usia 3-5 tahun tergolong gold period, dimana perkembangan di usia dini tidak bisa berulang. Oleh karena itu, pengetahuan tentang stimulasi menjadi suatu hal yang penting.

Tingkat pengetahuan seseorang dipengaruhi oleh faktor internal (pendidikan, pekerjaan, umur) dan eksternal (lingkungan dan sosial budaya). Hasil penelitian diatas menunjukkan bahwa terdapat hubungan signifikan antara tingkat pengetahuan ibu dalam pemberian stimulasi dengan perkembangan anak usia 3-5 tahun. Hasil tersebut didukung oleh penelitian milik Jasmawati \& Ratnawati (2016) di TK Al-Jawahir Samarinda, terhadap 82 responden didapatkan 56 (68.3\%) memiliki anak dengan perkembangan sesuai usia dengan $\mathrm{p}$ value $(0.000<0.05)$ yang artinya ada hubungan signifikan antara tingkat pengetahuan ibu tentang stimulasi terhadap perkembangan anak usia 4-6 tahun.

Pada penelitian ini, mayoritas sebanyak 31 ibu dengan tingkat pengetahuan baik memiliki anak yang perkembangannya sesuai sebanyak 31 anak $(88,6 \%)$. Sesuai hasil tersebut, tingkat 
pengetahuan ibu menjadi suatu hal penting dan sangat bermanfaat untuk proses perkembangan anak. Melalui pengetahuan yang memadai, maka bisa segera mengenali kendala yang ditemukan anak pada setiap aspek perkembangan. Ibu dengan tingkat pengetahuan tinggi tentang stimulasi perkembangan anak akan 6,96 kali lebih berpotensi untuk memiliki anak dengan perkembangan yang normal (Devi Firdaus, 2018).

Selain itu, didapatkan hasil penelitian yakni ibu memiliki tingkat pengetahuan baik namun perkembangan anak dalam kategori meragukan sebanyak 4 anak $(11,4 \%)$. Hal ini berarti meskipun ibu didukung oleh pengetahuan ibu baik, namun jika tidak memberikan stimulasi kepada anak maka perkembangan menjadi tidak optimal bahkan bisa mengakibatkan penyimpangan perkembangan (Marischa, 2015). Hasil diatas serupa dengan uraian dalam penelitian Zukhra \& Amin (2017) yang mana didapat pengetahuan ibu yang baik dengan perkembangan anak dalam kategori penyimpangan sebanyak 9 anak $(25,7 \%)$ dan meragukan 18 anak (51,4\%). Hasil penelitian diatas dipengaruhi oleh karakteristik responden seperti usia. Usia ibu didominasi oleh 24-33 tahun yang termasuk usia reproduktif sehingga mayoritas jumlah ibu yang memiliki tingkat pengetahuan yang baik.

Berdasarkan hasil penelitian diatas, tidak sedikit perkembangan anak yang menyimpang yaitu sebanyak 16 responden (33,3\%). Hal itu disebabkan oleh ibu mempunyai pengetahuan yang kurang tentang stimulasi anak. Untuk keberhasilan stimulasi, ibu perlu memperhatikan berbagai hal antara lain faktor awal stimulasi, berapa lama, bagaimana proses serta cara melaksanakannya. Peneliti menemukan ibu dengan tingkat pengetahuan kurang tidak memberikan stimulasi dini, ditinjau dari teori stimulasi perkembangan sebaiknya dilakukan sejak masa janin dalam kandungan, karena di dalam kandungan janin sudah bisa bernafas, mendengar, menendang, menggeliat, bergerak, menelan dan menghisap jempol (Luana, 2016).

Selain itu, lamanya stimulasi dikaitkan pada status bekerja. Ibu yang bekerja akan tersita waktunya diluar untuk mengurus pekerjaannya, sehingga durasi bertemu anak dan memberikan stimulasi pun sangat terbatas, akibatnya akan berpengaruh pada perkembangan anak. Kemudian, stimulasi anak bisa dipengaruhi oleh lingkungan yang mendukung (penuh dengan stimulasi). Lingkungan yang identik dengan tersedianya alat permainan untuk menstimulus perkembangan (Zukhra \& Amin, 2017).

Pada saat di lapangan pun, ibu banyak memberikan jawaban bahwa stimulasi bisa dilakukan ketika anak sedang mengantuk dan bosan. Hal tersebut bertentangan dalam teori Sulistyawati (2019) yang mengungkapkan bahwa prinsip stimulasi yaitu dilakukan pada waktu dan variasi yang menyenangkan. Dengan demikian, ibu yang didasari pengetahuan yang baik akan timbul keinginan untuk memberikan stimulasi perkembangan. Ibu tahu betul stimulasi perkembangan yang harus dilakukan secara terus menerus serta tentunya sesuai dengan tahapan usia anak. Akibatnya, anak bisa memiliki perkembangan sesuai dengan tahapan usianya. Peneliti dapat menyimpulkan bahwa tingkat pengetahuan ibu yang baik mempengaruhi perkembangan anak yang sesuai.

Tabel 11 Hubungan Sikap Ibu dalam Pemberian Stimulasi dengan Perkembangan Anak Usia 3-5 Tahun

\begin{tabular}{|c|c|c|c|c|c|c|c|c|c|}
\hline \multirow{3}{*}{ Sikap Ibu } & \multicolumn{6}{|c|}{ Perkembangan Anak } & \multirow{2}{*}{\multicolumn{2}{|c|}{ Total }} & \multirow[t]{3}{*}{$\begin{array}{c}P- \\
\text { Value }\end{array}$} \\
\hline & \multicolumn{2}{|c|}{ Sesuai } & \multicolumn{2}{|c|}{ Meragukan } & \multicolumn{2}{|c|}{ Ada Penyimpangan } & & & \\
\hline & $\mathbf{n}$ & $\%$ & $\mathbf{n}$ & $\%$ & $\mathbf{n}$ & $\%$ & $\mathbf{n}$ & $\%$ & \\
\hline Positif & 31 & 79,5 & 8 & 20,5 & 0 & 0 & 39 & 100 & 0,000 \\
\hline Negatif & 0 & 0 & 28 & 63,6 & 16 & 36,4 & 44 & 100 & \\
\hline Total & 31 & 37,3 & 36 & 43,4 & 16 & 19,3 & 83 & 100 & \\
\hline
\end{tabular}

Berdasarkan Tabel 11 terhadap 83 responden menunjukkan bahwa ibu dengan sikap positif dalam memberikan stimulasi memiliki anak dengan perkembangan yang sesuai sebanyak 31 anak $(79,5 \%)$, ibu yang memiliki sikap positif memiliki anak dengan perkembangan meragukan sebanyak 8 anak $(26,1 \%)$, ibu yang memiliki sikap negatif memiliki anak dengan perkembangan meragukan 
sebanyak 28 anak $(63,6 \%)$ serta memiliki anak yang perkembangannya menyimpang sebanyak 16 anak $(19,3 \%)$.

Berdasarkan hasil uji Chi Square dengan hasil nilai p sebesar 0,000 $<0,05$ yang berarti terdapat hubungan signifikan sikap ibu dalam pemberian stimulasi dengan perkembangan anak usia 3-5 tahun. Sikap ialah respon atau reaksi dari seseorang yang tertutup pada suatu obyek dan stimulus. Dalam hal ini, sikap akan dianggap menjadi syarat munculnya tindakan (Priyoto, 2020). Pada penelitian ini, sifat dari sikap ibu terdiri dari sikap positif dan negatif. Adapun faktor yang mempengaruhi munculnya sikap seseorang diantaranya pengalaman pribadi, anggapan pentingnya pengaruh orang lain, pengaruh kebudayaan, media massa, lembaga pendidikan dan agama serta faktor emosional (Wawan \& M, 2018).

Seorang ibu dapat dikatakan bersikap positif jika dalam berkomunikasi, ibu selalu merespon positif tentang perkembangan anaknya. Pada penelitian ini, ibu yang bersikap positif mampu menerima bahwa stimulasi harus diberikan kepada anak. Selain itu, ibu memberikan kesempatan kepada anak untuk memilih aktivitas yang ingin dilakukan dan anak didukung untuk melakukan hal yang disukai. Sikap tersebut akan membuat anak menemukan pengalaman baru. Sikap positif lain yang ditunjukkan ibu yaitu dapat menghargai setiap respon dari anak yang diberikan stimulasi.

Hasil penelitian diatas menunjukkan ada hubungan signifikan antara sikap ibu dalam pemberian stimulasi dengan perkembangan anak. Hasil tersebut diperkuat oleh penelitian Wahyuni (2018) terhadap ibu dengan anak usia 3-4 tahun di Kelurahan Balowerti Kota Kediri bahwa terdapat hubungan sikap orang tua dengan perkembangan anak ditandai dengan ( $p$ value $=0,002$ ) dan tingkat hubungan cukup kuat $(\mathrm{r}=0,697)$ serta arah hubungan positif $(\mathrm{r}=+0,697)$.

Berdasarkan hasil penelitian diatas diperoleh ibu dengan sikap negatif memiliki anak yang perkembangan meragukan sebanyak 28 anak $(63,6 \%)$ serta memiliki anak yang perkembangannya menyimpang sebanyak 16 anak (19,3\%). Peneliti menganalisis bahwa hal itu terjadi karena berkaitan dengan pengetahuan ibu. Pengetahuan ibu turut serta mempengaruhi ibu dalam bersikap kepada anaknya. Hal itu dibuktikan dari penelitian bahwa ibu yang memiliki pengetahuan tentang stimulasi perkembangan anak cenderung menciptakan lingkungan yang mendukung untuk munculnya kemampuan anak. Pada hasil penelitian diperoleh bahwa mayoritas tingkat pengetahuan ibu kurang, maka ibu cenderung bersikap negatif kepada anaknya (Sulistiyawati \& Mistyca, 2016).

Pernyataan itu dapat digambarkan pada jawaban responden dimana beberapa ibu menyatakan anak bisa berkembang dengan sendirinya. Hal tersebut bertentangan dengan teori Islamiyati \& Sadiman (2018) bahwa peran ibu sangatlah penting dalam mendidik anak, yaitu memenuhi berbagai kebutuhan anak, dalam hal ini adalah memberikan stimulasi perkembangan. Selain daripada itu, didapatkan hasil jawaban pada ibu dengan status aktif bekerja bahwa sebagian besar ibu bersikap negatif karena merasa keberatan memberikan stimulasi pada anak karena tidak punya waktu. Oleh sebab itu, masih terdapat ibu yang memiliki anak dengan perkembangan meragukan dan menyimpang.

Adapun analisa dari hasil penelitian diatas dimana ibu memiliki ibu yang memiliki sikap positif namun perkembangan anaknya masuk pada kategori meragukan sebanyak 8 anak $(26,1 \%)$. Analisis dari penelitian ini memperlihatkan bahwa kejadian ini dialami berkaitan oleh status bekerja pula, ibu yang bekerja sudah bersikap positif seperti menyempatkan waktu memberikan stimulasi, menghargai setiap respon anak, menyediakan alat permainan untuk merangsang kemampuan anak. Namun, pemberian stimulasi dengan melatih kemampuan dasar anak tidak dilakukan secara rutin.

Sementara, prinsip pemberian stimulasi yang dikemukakan oleh Sulistyawati (2019) ialah harus bertahap dan berkelanjutan sesuai usia anak yang mengacu pada aspek kemampuan dasar. Oleh karena itu, cara efektif dalam merubah sikap ibu ialah dengan pemberian informasi bermanfaat tentang kelebihan dan dampak stimulasi yang didapat dari tenaga kesehatan ataupun media massa, sehingga bisa menciptakan pemahaman baru serta mengubah pola pikir ibu. Berdasarkan uraian diatas bisa disimpulkan bahwa sikap ibu dalam pemberian stimulasi dapat mempengaruhi perkembangan anak. 
Tabel 12 Hubungan Motivasi Ibu dalam Pemberian Stimulasi dengan Perkembangan Anak Usia 3-5 Tahun

\begin{tabular}{|c|c|c|c|c|c|c|c|c|c|}
\hline \multirow{3}{*}{ Motivasi Ibu } & \multicolumn{6}{|c|}{ Perkembangan Anak } & \multirow{2}{*}{\multicolumn{2}{|c|}{ Total }} & \multirow{3}{*}{$\begin{array}{c}P- \\
\text { Value }\end{array}$} \\
\hline & \multicolumn{2}{|c|}{ Sesuai } & \multicolumn{2}{|c|}{ Meragukan } & \multicolumn{2}{|c|}{ Ada Penyimpangan } & & & \\
\hline & n & $\%$ & $\mathbf{N}$ & $\%$ & $\mathbf{n}$ & $\%$ & $\mathrm{n}$ & $\%$ & \\
\hline Termotivasi & 31 & 81,8 & 6 & 16,2 & 0 & 0 & 37 & 100 & 0,000 \\
\hline Tidak & 0 & 0 & 30 & 65,2 & 16 & 34,8 & 46 & 100 & \\
\hline Termotivasi & & & & & & & & & \\
\hline Total & 31 & 37,3 & 36 & 43,4 & 16 & 19,3 & 83 & 100 & \\
\hline
\end{tabular}

Berdasarkan Tabel 12 terhadap 83 responden menunjukkan bahwa ibu yang termotivasi dalam memberikan stimulasi memiliki anak dengan perkembangan yang sesuai sebanyak 31 anak $(83,8 \%)$, dan ibu yang termotivasi memiliki anak dengan perkembangan meragukan sebanyak 6 anak (16,2\%). Sementara ibu yang tidak termotivasi dalam memberikan stimulasi memiliki anak dengan perkembangan meragukan sebanyak 30 anak $(65,2 \%)$ dan anak dengan penyimpangan perkembangan sebanyak $16(34,8 \%)$.

Berdasarkan hasil uji Chi Square dengan hasil nilai p sebesar 0,000 < 0,05 yang bermakna H0 diterima atau H1 ditolak, serta bisa diambil kesimpulan bahwa motivasi ibu dalam pemberian stimulasi memiliki hubungan yang signifikan dengan perkembangan anak usia 3-5 tahun. Motivasi berasal dari kata motif yang berarti kekuatan untuk menggerakkan seseorang agar bertindak. Motivasi juga diartikan sebagai kemauan yang muncul dari diri seseorang untuk melakukan kegiatan agar sampai pada tujuan tertentu. Maka dapat dikatakan motivasi ibu dalam pemberian stimulasi yakni kemauan ibu dalam memberikan stimulasi atas kesadaran dirinya supaya perkembangan anak bisa sesuai. Motivasi memberi perbedaan antara ibu yang mau melakukan dan mampu melakukan, maka dari itu, motivasi mengacu pada kepada yang mau melakukan.

Pada penelitian Junaidi (2016) menguraikan bahwa seseorang yang tidak termotivasi terhadap suatu kegiatan akan menentukan tingkat peran sertanya terhadap kegiatan tersebut, dengan demikian apabila ibu memiliki motivasi yang kuat atau tertinggi, akan terlihat peran sertanya seperti pemenuhan kebutuhan stimulasi anak. Hal ini menggambarkan bahwa motivasi erat kaitannya dengan partisipasi.

Hasil penelitian diatas menunjukkan bahwa terdapat hubungan signifikan antara motivasi ibu dalam pemberian stimulasi dengan perkembangan anak usia 3-5 tahun. Penelitian yang menunjang hasil ini disampaikan oleh (Yuliana, 2016) di TK Nurul Izzah Yogyakarta didapati p value bernilai 0,0001 < 0,05 yang bermakna ada hubungan signifikan antara motivasi ibu tentang stimulasi dini dengan perkembangan pada anak usia 48 bulan. Hasil penelitian ini sesuai dengan teori yang diungkapkan Hurlock dimana salah satu faktor yang berpengaruh pada perkembangan anak yaitu dorongan (motivasi).

Adapun hasil diatas dimana ibu yang memiliki motivasi dalam memberikan stimulasi memiliki anak dengan perkembangan yang sesuai sebanyak 31 anak (83,8\%). Hasil yang menunjang penelitian ini dari Yuliana (2016) yaitu ibu yang memiliki motivasi tentang stimulasi dini sebagian besar perkembangan anak pada kategori normal sebanyak 20 responden $(100,0 \%)$. Peneliti menganalisis bahwa pada ibu yang termotivasi akan memberikan stimulasi rutin, kemudian anak akan selalu menerima stimulasi yang benar serta terarah sehingga mampu melakukan hal positif atau kemampuan sesuai aspek perkembangan yang seharusnya bisa dicapai.

Berdasarkan hasil penelitian, karakteristik responden turut mempengaruhi motivasi ibu seperti usia ibu, ibu dengan rentang usia 34-43 biasanya sudah memiliki anak lebih dari 1 sehingga memiliki lebih banyak pengalaman dalam mengurus anak, dengan begitu berpeluang untuk lebih termotivasi memberikan stimulasi kepada anak keduanya.

Pada penelitian ini, ditemukan ibu yang termotivasi dengan perkembangan anaknya meragukan sebanyak 6 anak (16,2\%). Sama seperti hasil (Yuliana, 2016) bahwa responden termotivasi memberikan stimulasi namun perkembangan anaknya meragukan. Berdasarkan analisis dari 
peneliti, hal itu dikarenakan karakteristik responden yang mana ibu aktif bekerja. Meskipun ibu termotivasi dalam menstimulasi anak, namun karena memiliki urusan pekerjaannya diluar maka tidak bisa dilakukan secara maksimal. Sehingga, ibu seringkali menitipkan pada pengasuh lain dirumah. Selain itu peneliti menganalisis bahwa ada kaitannya dengan pengetahuan responden.

Dalam pemberian stimulasi, ibu yang termotivasi juga perlu informasi yang tepat dan benar sehingga stimulasi yang didapat anak akan bermanfaat dan tidak menimbulkan kerugian atau efek samping. Disamping itu, mayoritas ibu tidak termotivasi dalam memberikan stimulasi memiliki anak yang berada pada kategori perkembangan meragukan sebanyak 30 anak $(65,2 \%)$ Ibu yang tidak memberikan stimulasi mengakibatkan anak akan mengalami keterlambatan perkembangan karena tidak mendapatkan dan menerima stimulasi dengan baik, sehingga anak menjadi tidak terarah bahkan tidak mengetahui apa yang seharusnya dilakukan.

Hal ini sesuai dengan teori Sulistyawati (2014) dimana perkembangan anak juga dipengaruhi dengan macam-macam faktor yakni faktor post-natal antara lain stimulasi, motivasi, kelompok sebaya, stres, sekolah, serta kualitas interaksi antara anak dan orang tua. Berdasarkan uraian diatas, bisa ditarik kesimpulan bahwa ada hubungan motivasi ibu dalam pemberian stimulasi dengan perkembangan pada anak. Semakin baik motivasi ibu dalam memberikan stimulasi maka perkembangan anak bisa sesuai.

Pada penelitian ini ditemukan keterbatasan dalam waktu pelaksanaan dan pengambilan data, karena beberapa sampel ibu bekerja tidak berada dirumah, maka dilakukan penjadwalan ulang sehingga proses menjadi lebih lama dan waktunya terbatas. Kemudian terdapat beberapa faktor karakteristik responden yang tidak dianalisis seperti keterpaparan media informasi, jumlah anak dan dukungan keluarga.

\section{SIMPULAN}

Ada hubungan antara tingkat pengetahuan ibu dengan perkembangan anak usia 3-5 tahun di Wilayah RW 04 Kelurahan Kedung Jaya. Ada hubungan antara sikap ibu dengan perkembangan anak usia 3-5 tahun di Wilayah RW 04 Kelurahan Kedung Jaya. Ada hubungan antara motivasi ibu dengan perkembangan anak usia 3-5 tahun di Wilayah RW 04 Kelurahan Kedung Jaya. Hal ini menunjukan ketiga variabel tersebut memiliki hubungan yang signifikan dengan perkembangan anak usia 3-5 tahun di Wilayah RW 04 Kelurahan Kedung Jaya.

\section{SARAN}

Rekomendasi kepada peneliti selanjutnya dapat melakukan penelitian berkelanjutan dengan menggunakkan metode quasi eksperimen yakni intervensi yang tepat untuk menstimulasi perkembangan anak usia 3-5 tahun. Penelitian juga dapat dilakukan dengan desain kualitatif yang bertujuan untuk menggali perasaan ibu yang sudah memberikan stimulasi kepada anak, dengan begitu akan mengetahui faktor-faktor lain yang terlibat dalam pemberian stimulasi. Peneliti dapat mencari hubungan status pekerjaan ibu dengan perkembangan anak serta direkomendasikan untuk melibatkan subjek lebih banyak.

\section{DAFTAR PUSTAKA}

Aboud, F. E., \& Yousafzai, A. K. (2019). Scaling up child psychosocial stimulation programmes for young children. The Lancet Global Health, 7(3), e294-e295. https:/ / doi.org/10.1016/S2214109X(19)30018-X

Anggraeni, R. (2018). Health Education Psychososial Development As An Effort Of To Prevent Physical And Verbal Violence Of School A Of School Aged Children In Kendal City. Jurnal Ners Dan Kebidanan, 5(2), 97-104. https://doi.org/10.26699/jnk.v5i2.ART.p097

Asiyah, N. (2018). Pengaruh Psikoedukasi Tentang Pengetahuan Kesiapan Sekolah Anak Terhadap Ibu Untuk Meningkatkan Kemandirian Anak TK Hasanuddin Surabaya. 10.

https:// webcache.googleusercontent.com/search?q=cache:BDsuQOHoCi4J:https:/ / media.neli ti.com/media/publications/9138-ID-perlindungan-hukum-terhadap-anak-dari-kontenberbahaya-dalam-media-cetak-dan-ele.pdf $+\& c d=3 \& h l=i d \& c t=c l n k \& g l=i d$

Berlianti, A., Sundari, N., \& Mashudi, E. A. (2020). Disorders Of Language Development In Children 4 Years Old Have A Speech Delay. 8, 1-12. 
Devi Firdaus, N. (2018). Hubungan Tingkat Pendapatan Keluarga, Tingkat Pengetahuan Ibu Tentang Stimulasi Perkembangan Anak, Dan Tingkat Pendidikan Ibu Dengan Perkembangan Sosial Anak Balita Di Kota Madiun. 192(4), 10.

http:/ / ec.europa.eu/energy/res/legislation/doc/biofuels/2006_05_05_consultation_en.pdf\% 0Ahttp://dx.doi.org/10.1016/j.saa.2017.10.076\%0Ahttps://doi.org/10.1016/j.biortech.2018.07. 087\%0Ahttps://doi.org/10.1016/j.fuel.2017.11.042\%0Ahttps://doi.org/10.1016/j.

Hamidah Hanim, J., \& Issn, P. K. (2020). Pengaruh Pendidikan Kesehatan Terhadap Pengetahuan Dan Sikap Ibu Tentang Deteksi Dini Tumbuh Kembang Balita Di Desa Gampong Jawa Kecamatan Langsa Kota Tahun 2019. 3(1), 44-53.

Hati, Febrina Suci; Lestari, P. (2017). The Influence of Stimulation in Children Aged 12-36 Months in Sedayu Regency , Bantul. Jurnal Ners Dan Kebidanan Indonesia, 4(1), 44-48.

Islamiyati, I., \& Sadiman, S. (2018). Stimulasi Psikososial Keluarga oleh Orang Tua terhadap Perkembangan Anak Usia 48-60 Bulan. Jurnal Kesehatan Metro Sai Wawai, 11(2), 65-70. https:// doi.org/10.26630/jkm.v11i2.1774

Jasmawati, \& Ratnawati. (2016). Hubungan Tingkat Pengetahuan Ibu Tentang Stimulasi Terhadap Perkembangan Anak Usia 4-6 Tahun Di TK Al-Jawahir Samarinda. Jurnal Husada Mahakam, IV (2), 81-91.

Junaidi. (2016). HUBUNGAN MOTIVASI IBU DENGAN PERKEMBANGAN BAHASA ANAK USIA TODDLER (1-3 TAHUN) DI POSYANDU MELATI DUSUN NGRAME TAMANTIRTO KASIHAN BANTUL YOGYAKARTA. Profesi Ners, 147, 11-40.

Katharina, T., \& Iit, K. (2018). Hubungan Antara Pengetahuan Ibu Dengan Sikap Terhadap Tumbuh Kembang Anak Usia 0-24 Bulan. Jurnal Kebidanan, 7(2), 134-141. https://doi.org/10.33486/jk.v7i2.28

Luana, W. M. (2016). Hubungan Pengetahuan Dengan Sikap Ibu Dalam Pemberian Stimulasi Perkembangan Psikososial Pada Anak Usia 3-5 Tahun Di Paud Al-Baraakah Sleman. 3(2), 356-369. https://www.metis2020.com/wpcontent/uploads/METIS_D1.4_v3.pdf\%0Ahttps://www.metis2020.com/documents/delivera bles/index.html\%0Ahttps:/ / www.metis2020.com/metis-deliverables-d1-4-d2-4-d3-3-d4-3-d65-and-d7-3-were-completed-in-february-2015/index.html\%0Ahttp

Marischa, S. (2015). Analisis tingkat pengetahuan orang tua tentang stimulasi dengan perkembangan motorik kasar anak usia 0-5 tahun. Fakultas Kedokteran Universitas Lampung, 2(4), 0-4.

Meilawati, E. N. (2017). Hubungan Pengetahuan Orang Tua Tentang Stimulasi Bermain Anak Dengan Perkembangan Motorik Halus Anak Usia 3-5 Tahun Di Paud Al Falah Desa Bibrik Kecamatan Jiwan Kabupaten Madiun.

Mulyanti, S., Chundrayetti, E., \& Masrul, M. (2017). Hubungan Stimulasi Psikososial dengan Perkembangan Anak Usia 3-72 Bulan di Wilayah Kerja Puskesmas Lubuk Begalung Padang. Jurnal Kesehatan Andalas, 6(2), 340. https://doi.org/10.25077/jka.v6i2.701

Prastiwi, M. H. (2019). Pertumbuhan Dan Perkembangan Anak Usia 3-6 Tahun. Jurnal Ilmiah Kesehatan Sandi Husada, 10(2), 242-249. https:/ / doi.org/10.35816/jiskh.v10i2.162

Priyoto. (2020). Teori Sikap dan Perilaku dalam Kesehatan (1st ed.). Nuha Medika.

Riyadi, E. K. S., \& Sundari, S. (2020). Tingkat Pengetahuan Orang Tua Tentang Stimulasi Perkembangan Anak Pra Sekolah Usia 60-72 Bulan. JURNAL ILMU KEBIDANAN, 6, 59-75.

Salifah, H. L. N. (2020). Studi Literatur Hubungan Stimulasi Terhadap Kesesuaian Tumbuh Kembang Anak Usia Pra Sekolah (Vol. 21, Issue 1). https:// doi.org/10.1016/j.tmaid.2020.101607\%250

Siswina, T., Shahib, N., \& Rasyad, A. S. (2016). Pengaruh Stimulasi Pendidikan Terhadap Perkembangan Kecerdasan Anak Usia 3-6 Tahun. Jurnal Ilmiah Bidan, 1(2), 27-33. https:/ / ejournal.ibi.or.id/index.php/jib/article/view/7/5

Sugeng, H. M., Tarigan, R., \& Sari, N. M. (2019). Gambaran Tumbuh Kembang Anak pada Periode Emas Usia 0-24 Bulan di Posyandu Wilayah Kecamatan Jatinangor. Jsk, 4(3), 96-101.

Sulistiyawati, \& Mistyca, M. R. (2016). Pengetahuan berhubungan dengan sikap ibu dalam kemampuan menstimulasi pertumbuhan dan perkembangan anak balita. Jurnal Ners dan Kebidanan Indonesia.

Sulistyawati, A. (2019). Deteksi Tumbuh Kembang Anak (A. Suslia (ed.)). Salemba Medika. 
Wahyuni, C. (2018). Hubungan Pengetahuan, Sikap dan Perilaku tentang Stimulasi Dini dengan Perkembangan Motorik Halus Anak Usia 1-3 Tahun di Kelurahan Balowerti Kota Kediri. Journal for Quality in Women's Health, 1(2), 35-42. https:// doi.org/10.30994/jqwh.v1i2.15

Wawan, A., \& M, D. (2018). Teori dan Pengukuran Pengetahuan, Sikap, dan Perilaku Manusia. Nuha Medika.

Wijayanti, A. R., \& Edmiandini, U. F. (2017). Hubungan Sikap Ibu Tentang Stimulasi Perkembangan Dengan Tahap Perkembangan Motorik Kasar Pada Anak Usia 3-4 Tahun. Jurnal Kebidanan, 10, 8-8. http://jurnal.stikeswilliambooth.ac.id/index.php/Keb/article/view/200

Yuliana. (2016). hubungan pemberian motivasi ibu tentang stimulasi dini dengan perkembangan pada anak usia 48 bulan di tk nurul izzah candirejo 2015.

Yunita, D., Luthfi, A., \& Erlinawati, E. (2020). Hubungan Pemberian Stimulasi Dini Dengan Perkembangan Motorik Pada Balita Di Desa Tanjung Berulak Wilayah Kerja Puskesmas Kampar Tahun 2019. Jurnal Kesehatan Tambusai, 1(2), 61-68.

Zukhra, R. M., \& Amin, S. (2017). Hubungan Tingkat Pengetahuan Orang Tua Tentang Stimulasi Tumbuh Kembang Terhadap Perkembangan Balita Di Wilayah Kerja Puskesmas Simpang Baru. Hubungan Tingkat Pengetahuan Orang Tua Tentang Stimulasi Tumbuh Kembang Terhadap Perkembangan Balita Di Wilayah Kerja Puskesmas Simpang Baru. 